\title{
Effects of Storage on Physicochemical Properties and Microbiological Qualities of African Breadfruit-Corn Yoghurt
}

\author{
D.I. Ifediba (M.Sc) \\ Department of Agricultural Technology/Processing, Anambra State \\ Polytechnic, Mgbakwu, Anambra State, Nigeria. \\ C.N. Ozoh (M.Sc) \\ Department of Science Laboratory Technologies, Anambra State \\ Polytechnic, Mgbakwu, Anambra State, Nigeria.
}

Doi: 10.19044/esj.2018.v14n6p172 URL:http://dx.doi.org/10.19044/esj.2018.v14n6p172

\begin{abstract}
African breadfruit-corn milk was obtained from blend of extracts of African breadfruit (Treculia africana var africana) and sweet corn (Golden cob F1) on 60:40 proportions. The breadfruit-corn milk was fermented to give a yoghurt-like product using inoculums from activated batch of dried starter culture and previously made breadfruit-corn milk. The breadfruit-corn yoghurt was stored in the refrigerator for four weeks, during which changes in physicochemical properties and microbiological qualities were examined weekly against commercial dairy yoghurt. It was found that changes in total solids, $\mathrm{pH}$, titratable acidity, apparent viscosity, syneresis, water holding capacity followed similar trends, except for the whey drainage of the commercial dairy yoghurt which was constant at 0.00 . The two yoghurt samples also exhibited similar microbiological changes during the period of study. Thus suggesting that non-dairy yoghurt from African breadfruit-corn milk shared common keeping characteristics with the dairy yoghurt.
\end{abstract}

Keywords: Yoghurt, Lactic acid bacteria, African breadfruit, Sweet corn, Physicochemical, Microbiological

\section{Introduction}

Yoghurt is a coagulated milk product obtained by lactic acid fermentation through the action of Streptococcus thermophilus and Lactobacillus delbrukei spp. bulgaricus, and the viability and activity of yoghurt bacteria are important commercial consideration so that they survive throughout shelf life, transit through acidic conditions in the stomach as well as enzymes and bile salts in the small intestine (Walia et al., 2013). 
Industrial production of yoghurt has increasingly developed world wide due to the nutritional benefit of milk constituents and live lactic acid bacteria (Afonso and Maia, 1999; Birollo, 2000; Park et al., 2005). The presence of lactic acid bacteria (LAB) in milk fermentation can be either spontaneous or inoculated starter culture since milk is known as one of the natural habitats (Wouters et al., 2002; Delavenne et al., 2012). Although under spontaneous fermentation the growth of LAB cannot be predicted or controlled, but the procedure has been practiced and carried out traditionally for years (Mennane et al., 2007; Sharma et al., 2012).

LAB has a role in milk fermentation to produce acid which is important as preservative agent and for generating flavor of product. They also produce exopolysaccharides which are essential for texture formation (Widyastuti et al., 2014). Considering the existing reports on several health promoting properties as well as their generally regarded as safe (GRAS) status of LAB they can be now widely used to ferment milk product (Panessar, 2011).

However, consumption of cow milk is avoided by vegetarians and people who are allergic to cow milk (Supavititpatana et al., 2010). As a result, therefore, enormous efforts are diverted towards making yoghurt from a variety of food resources (Granata and Morr, 1996; Lal et al., 2006). Yoghurtlike products have been developed from several plant sources such as banana (Wheeler and Gulufes, 1973), cowpea and mung beans (Rao et al., 1988), soybeans (Buono et al., 1990), peanut (Isanga and Zhang, 2009), corn (Supavititpatana et al., 2010). Yoghurt-like products have equally been made by combining two or more plant materials such as tiger nut-coconut (Belewu et al., 2010), soybean-corn (Olakunle 2012; Lestiyani et al., 2014), peanutsoybean (Kpodo et al., 2014a). In addition, yoghurt has been developed from blend of plant and dairy milk as in soy and milk solids yoghurt (Zhanlis and Jideani, 2012), soy - peanut-cow milk yoghurt (Kpodo et al., 2014b), mangosoy skimmed milk fortified yoghurt (Kumar and Mishra, 2004), peanut milkbased yoghurt fortified with skimmed milk powder (Elsamani et al., 2014).

The microorganisms that have been implicated in the fermentation of dairy and non-dairy yoghurt include Streptococcus thermophilus and Lactobacillus bulgaricus. The mutual benefit between them occur by releasing the amino acids from the milk as well as organic acids and therefore they produce more lactic acid and aromatic compounds and texture, by converting milk protein due to their proteolytic activities (Mayra-Makinen and Bigret, 2004; Kongo, 2013). The mild acidification of the milk protects the yoghurt against spoilage microorganisms and proliferation of pathogens and mild acid taste and pleasant fresh characteristics of fermented milk products such as yoghurt and cheese. Both acids and bacteriocins are great potentials to be used in food preservation, which are considered as safe natural preservatives (Moon et al., 2012). 
Apart from the general benefits of yoghurts, non-dairy yoghurt offer several distinct nutritional advantages over cow milk yoghurt, to the consumer, such as reduced level of cholesterol, saturated fats and lactose (Lee et al., 1990). African breadfruit-corn yoghurt will expectedly contribute to the efforts made towards developing dairy free yoghurts that satisfy religious, health and economic peculiarities of our time.

\section{Materials and method}

\section{Sources of raw materials}

Fresh seeds of African breadfruit (Treculia africana var africana) were purchased from Oye Agu Market, Abagana, Njikoka L.G.A., Anambra State, Nigeria. Green field sweet corn (Golden cob F1) was purchased from Songhai Farm, Heneke, Ezeagu L.G.A., Enugu State, Nigeria.

\section{Production of sample}

Production of yoghurt sample commenced shortly after purchase and subsequent preparation of the raw materials.

\section{Preparation of raw materials}

The breadfruit seeds were washed in excess volume of water to remove extraneous materials and deformed seeds, drained and parboiled in water at $95^{\circ} \mathrm{C}$ for 15 min with constant stirring. The parboiled seeds were drained, air dried and dehulled in a hand mill ( Corona, Landers YCIA, South Africa) whose teeth gap was adjusted to approximately $15 \mathrm{~mm}$ to crack the seeds without crushing. This was winnowed to remove the hull and washed in potable water. The green field sweet corn was firstly husked, the silks removed and washed in potable water. The grains were separated from the cob using knife and cleaned to remove adhering materials.

\section{Production of breadfruit-corn milk}

\section{The milk blending method of Udeozor (2012) was used.}

Approximately $2 \mathrm{~kg}$ of the breadfruit cotyledons were soaked in potable water for $6 \mathrm{~h}$, with soak water changed every $2 \mathrm{~h}$, to avoid fermentation and to eliminate foul odour and greasy substances. They were repeatedly washed before wet-milling in a variable speed blender (SB-736, Sonic, Japan), with intermittent addition of distilled water. The slurry was filtered through double layer linen cloth, wet-milled and filtered repeatedly to final seeds to water ratio of 1:3 (w/v). The filtrate was boiled for $20 \mathrm{~min}$ with continuous stirring, re-filtered to obtain plain breadfruit milk. Again, approximately $2 \mathrm{~kg}$ of corn grains were soaked in potable water for $6 \mathrm{~h}$ and the soak water changed as before. The grains were repeatedly washed, wet-milled and filtered as before to a final grain to water ratio of 1:3 (w/v). The filtrate was boiled for 
15 min, re-filtered to give plain corn milk extracts. The two extracts were blended on breadfruit milk: corn milk of 60:40 proportions (v/v) to obtain breadfruit-corn milk used for yoghurt production.

\section{Production of breadfruit-corn yoghurt}

The methods reported by Miral and Steinkraius (1999) and Jimoh and Kolapo (2007) were slightly modified.

Vegan yoghurt starter culture could not be sourced locally as at the time of this study. A starter culture (Yogourmet, Canada) containing Streptococcus thermophilus, Lactobacillus bulgaricus and L. acidophilus was used according to manufacturer specifications. However, using the free dried pack of this starter did not give expected result after the prescribed incubation period. Extending the fermentation duration and varying incubation temperature did not yield the desired coagulum. The product was however put in tight lid container and preserved in the refrigerator to serve as activation batch. Subsequently, exactly $2 \mathrm{~L}$ of plain breadfruit-corn milk was pasteurized at $88^{\circ} \mathrm{C}$ for $15 \mathrm{~min}$ and left to cool to $45^{\circ} \mathrm{C}$. Approximately $200 \mathrm{ml}$ of culture was drawn aseptically from the activation batch to inoculate the $2 \mathrm{~L}$ milk. This was stirred with sterile spoon to evenly distribute the inoculums, incubated at $45 \pm 2{ }^{\circ} \mathrm{C}$ for about $8 \mathrm{~h}$ to achieve better gel structure. The set yoghurt was placed in the refrigerator for $3 \mathrm{~h}$ to stop fermentation. About $5 \%$ of sucrose, $0.02 \%$ of carboxyl methyl cellulose $(\mathrm{CMC})$ and preservatives $(0.01 \%$ sodium benzoate and $0.01 \%$ potassium sorbate) were added to the coagulum, stirred to mix, filled into screw capped plastic bottles and stored in the refrigerator.

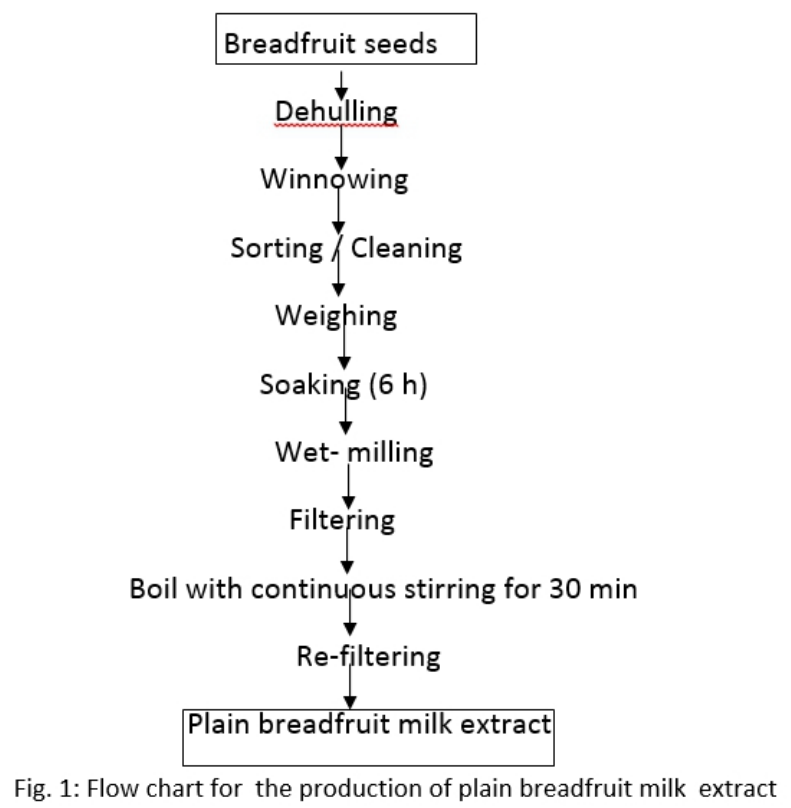




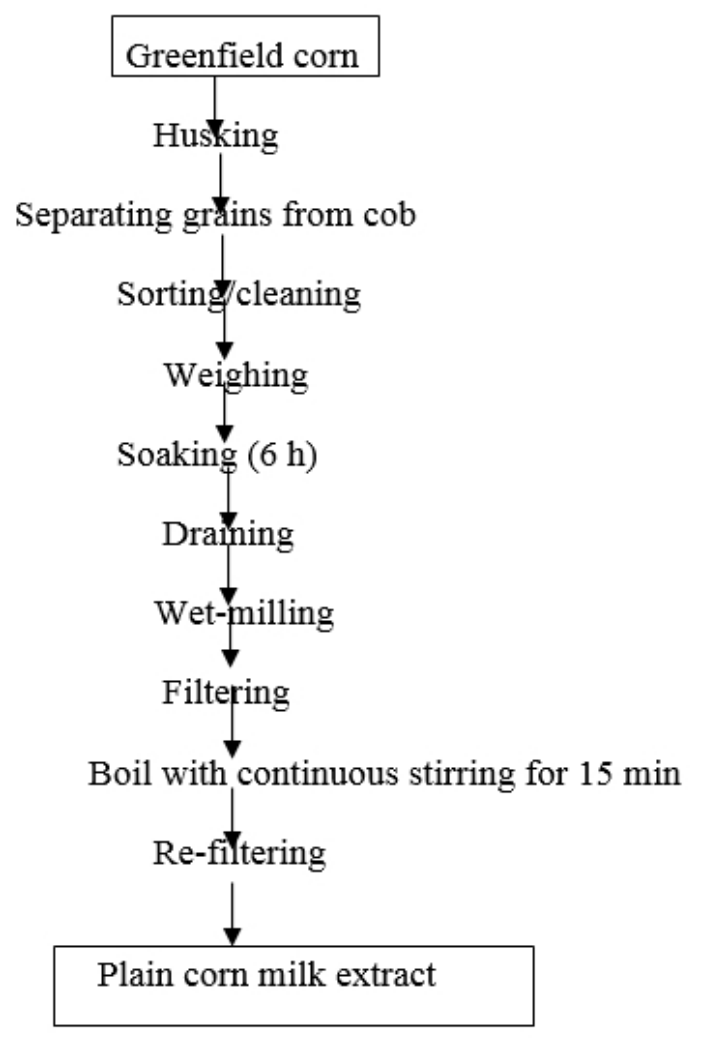

Fig. 2: Flow chart for the production of plain corn milk extract

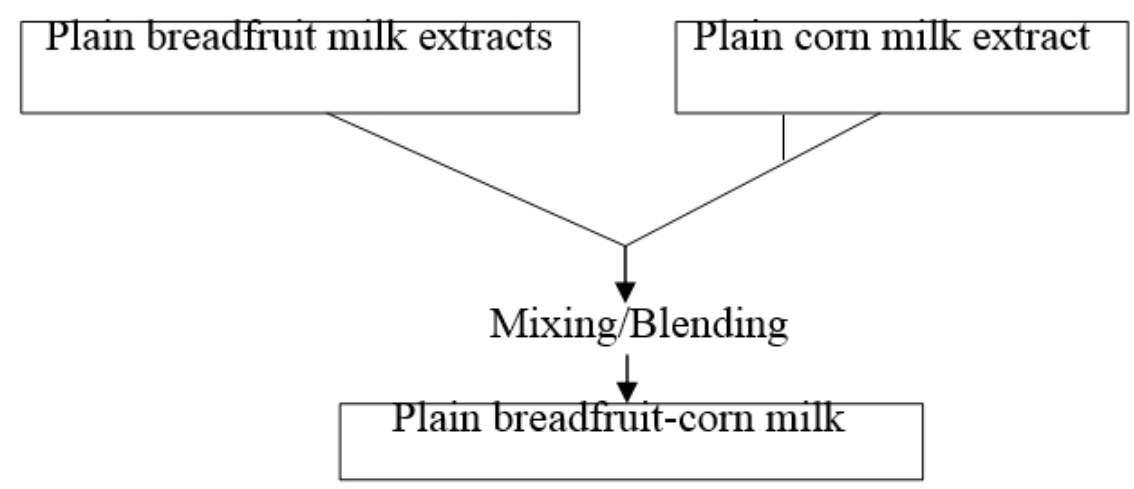

Fig. 3: Flow chart for the production of plain breadfruit-corn milk 


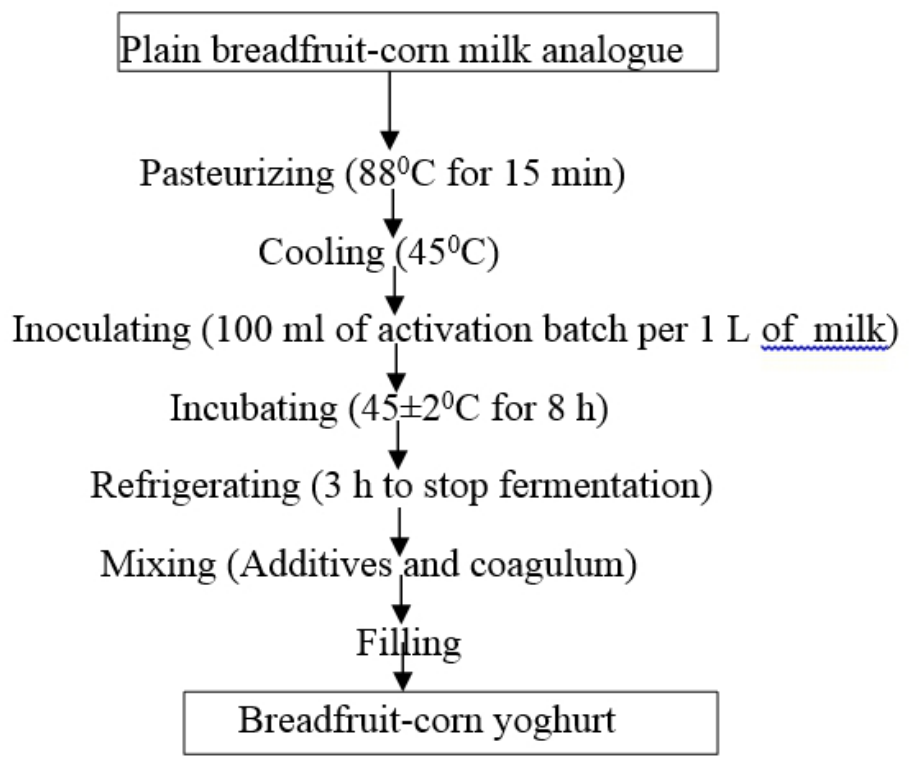

Fig. 4: Flow chart for the production of breadfruit-corn yoghurt

\section{Commercial cow milk yoghurt}

The commercial cow milk yoghurt which was produced the same day as the breadfruit-corn yoghurt was obtained from a manufacturer in Nigeria for comparative analysis.

\section{Physicochemical analysis}

\section{Total solids}

Total solid was obtained by differential method. $\%$ Total solids $=100-$ Moisture content

\section{pH}

The $\mathrm{pH}$ of samples was measured by electrometric method using Laboratory pH Meter Hanna model HI991300 (APHA, 1998).

The $\mathrm{pH}$ electrode was rinsed with distilled water and blot dry before rinsing in a small beaker with a portion of the sample. Sufficient amount of the sample was poured into a small beaker to allow the tips of the electrode to be immersed to a depth of about $2 \mathrm{~cm}$. The electrode was at least $1 \mathrm{~cm}$ away from the sides and bottom of the beaker. The temperature adjustment dial was adjusted accordingly. The $\mathrm{pH}$ meter was turned on and the $\mathrm{pH}$ of sample recorded.

\section{Titratable acidity}

The method described by Lestiyani et al. (2014) was applied. Exactly $10 \mathrm{ml}$ of yoghurt sample was mixed with $100 \mathrm{ml}$ of distilled water. 
Phenolphthalein (1\%) indicator was added and then titrated with $0.1 \mathrm{~N} \mathrm{NaOH}$ to a persistent pink color. The titratable acidity was reported as \% lactic acid by weight using $1 \mathrm{ml} 0.1 \mathrm{~N} \mathrm{NaOH}=0.0090 \mathrm{~g}$ lactic acid (AOAC, 1990).

\section{Apparent viscosity}

Approximately $30 \mathrm{ml}$ of sample was filled into a $50 \mathrm{ml}$ beaker.

Viscosity was measured using Oswald type viscometer.

\section{Syneresis}

Syneresis was measured using the method described by Supavititpatana et al. (2010). $\quad$ About $20 \mathrm{~g}$ of yoghurt sample was spread on Whatman filter paper and was filtered under vacuum. The filtrate was weighed and expressed as a percentage of the yoghurt weight.

\section{Whey drainage}

The method described by Supavititpatana et al. (2010) was used. Whey drainage was removed from yoghurt samples using a syringe within $24 \mathrm{~h}$ after the yoghurt formation has completed. The relative amount of whey drained off (in $\mathrm{ml}$ per $100 \mathrm{ml}$ ) of initial sample was calculated as the whey drainage.

\section{Water holding capacity}

The method of Parnell-Clunies et al. (1986) was used. About $10 \mathrm{~g}$ sample was centrifuged at 3,000 rpm for $60 \mathrm{~min}$ at $10^{\circ} \mathrm{C}$. The supernatant was removed within $10 \mathrm{~min}$ and the weight of the pellet was recorded. The water holding capacity was expressed as percentage of pellet weight relative to the original weight of yoghurt.

\section{Microbiological analysis}

Total viable count and mould count were carried out according to the method described by Ogbulie et al. (1998) for serial dilution and plating.

\section{Total viable count}

The plates, test tubes and pipettes used were previously sterilized at $160^{\circ} \mathrm{C}$ for $1 \mathrm{~h}$ in an electric oven. The test tubes were labeled in the order of $10^{-1}$ to $10^{-6}$ each filled to $9 \mathrm{ml}$ volume with distilled water. A sterile $1 \mathrm{ml}$ pipette was used to transfer aseptically $1 \mathrm{ml}$ of the sample into the first test tube marked $10^{-1}$. The test tube was rocked to mix thoroughly and $1 \mathrm{ml}$ aliquot was transferred into the $10^{-2}$ tube using sterile pipette and $1 \mathrm{ml}$ aliquot was transferred into $10^{-3}$ test tube, and this was continued up to the $10^{-6}$ test tube.

The total viable count of the samples were carried out by inoculating $0.1 \mathrm{ml}$ from $10^{-3}$ to $10^{-5}$ dilutions on plates of set sterile nutrient agar, in duplicates for each. The plates were incubated at $37^{\circ} \mathrm{C}$ for $48 \mathrm{~h}$ after which 
colonies formed were counted and expressed in colony forming units per milliliter $(\mathrm{cfu} / \mathrm{ml})$.

\section{Mould count}

Serial dilution was carried out as before. The mould count for each sample was carried out by inoculating $0.1 \mathrm{ml}$ from $10^{-3}$ and $10^{-4}$ dilutions in duplicates for each of set plates of already sterilized sabourand dextrose agar. The plates were incubated at $25^{\circ} \mathrm{C}$ for 3 to 5 days after which the colony counts per milliliter $(\mathrm{cfu} / \mathrm{ml})$ were recorded.

\section{Results and discussion \\ Physicochemical properties \\ Chemical properties}

The total solids content of commercial milk yoghurt was much higher than that of the breadfruit-corn yoghurt as seen in Fig. 5. The total solids of the breadfruit-corn yoghurt of $14.30 \%$ are however higher than the $12.25 \%$ of corn milk yoghurt as reported by Supavititpatana et al. (2010) and $11.0 \%$ of soy-corn yoghurt of Olakunle (2012). Also, the total solids of the commercial cow milk yoghurt in this study were $22.16 \%$ compared to $21.56 \%$ of the commercial yoghurt used for the same purpose by Supavititpatana et al. (2010). The higher value of total solids in the commercial milk yoghurt may be due to the skimmed milk powder from which it was constituted. Elsamani et al. (2014) reported an increase in total solids of peanut milk based yoghurt with addition of skimmed milk powder. This agreed with previous findings by Rehman et al. (2009) on increase in total solids of lathyrus sativus Lbovine milk by addition of skimmed milk powder. Similarly, increase in the total solids content of soy milk fortified yoghurt occurred with the concentration of both soymilk powder and non-fat dried milk (Zanhi and Jideani, 2012). The total solids of both yoghurts decreased during the four week storage in the refrigerator. This observation slightly differed from the findings of Supavititpatana et al. (2010) who reported decrease in soluble solids only. Walia et al. (2013) reported persistent decrease in total solids during yoghurt fermentation. This reduction may be due to the utilization of sugar by the starter cultures (Vasiljeric and Jelen, 2002; Wang et al., 2002).

The $\mathrm{pH}$ of the breadfruit-corn yoghurt was higher than that of the commercial milk yoghurt as shown in Fig .6. The lower $\mathrm{pH}$ of commercial milk yoghurt may be due to the skimmed milk powder used in the production as well as fermentation time. Elsamani et al. (2014) reported lower $\mathrm{pH}$ in sample with highest skimmed milk powder addition. Skimmed milk powder addition increases the concentration of lactose that could be degraded by the starter culture enzymes to produce lactic acid (Kpodo et al., 2014b). This acid in turn increases the acidity and automatically reduces the $\mathrm{pH}$. Onweluzo and 
Nwakalor (2009) reported similar relationship between $\mathrm{pH}$ and acidity. Walia et al. (2013) reported that fermentation time had a positive effect on acidity but a negative effect on $\mathrm{pH}$, total solids, reducing and total sugars in mango soy fortified yoghurt. Although the breadfruit-corn yoghurt contained corn protein (zein) that may lower the $\mathrm{pH}$, the acidification effect of skim milk could bear more influence owing to faster utilization of lactose by the fermenting microorganisms. In addition, the commercial milk yoghurt used equally contained corn starch as declared on the label, an indication that the zein protein may have equally contributed to the acidity. However, the $\mathrm{pH}$ of the breadfruit-corn yoghurt of 4.98 correlated with those of soy-corn yoghurts of 4.5 (Olakunle, 2012) and 4.76 (Lestiyani et al., 2014). Again, Fig .6 shows that $\mathrm{pH}$ of both yoghurts decreased during storage. Supavititpatana et al. (2010) reported similar trend in $\mathrm{pH}$ reduction during 35 days of corn milk yoghurt and commercial milk yoghurt storage, with greater reduction found in corn milk yoghurt. DeVos (1996) reported that when lactic acid is produced in yoghurt and $\mathrm{pH}$ has reached 4.0, Lactobacillus bulgaricus ceases their metabolic activity and lactose is not further utilized. By re-routing metabolism of the lactic acid bacteria towards production of more $\mathrm{pH}$ neutral components further conversions of lactose is possible.

It can be seen in Fig. 7 that the initial titratable acidity of the breadfruitcorn yoghurt was lower than that of commercial milk yoghurt as a consequence of the higher acidification effect of skim milk based beverages. Rehman et al. (2007) reported highest acidity in milk sample for the sample with highest content of skim milk which concurred with earlier findings by Chien and Synder (1983) as well as Sexane and Singh (1997). The higher titratable acidity of the commercial milk yoghurt might be due to the different kind of substrate in relation to that of breadfruit-corn yoghurt. The main substrate in dairy milk is lactose but sucrose in sweet corn is a major substrate of the breadfruit-corn yoghurt. Streptococcus thermophillus and Lactobacillus bulgariccus have an ability to consume lactose and fructose and convert them to lactic acid via Embeden- Meyerhof-Parnas (EMP) pathway, but $L$. bulgariccus is unable to convert the sucrose into lactic acid via EMP pathway because the bacteria do not produce invertase (Estedez et al., 2008). It was also observed that the acidity of the yoghurt samples increased during the 28 days storage. This increase in acidity during storage agreed with the findings of Supavititpatana et al. (2010) and Adeiye et al. (2013) for corn milk yoghurt and groundnut milk respectively. Similarly, Walia et al. (2013) reported that acidity of mango-soy fortified yoghurt increased from 0.13 at $0 \mathrm{~min}$ to 0.62 at 270 min of fermentation. The increase in titratable acidity may be as a result of anaerobic microbial activities resulting in the formation of lactic and other organic acids. It has been reported that increase in titratable acidity and the extent of increase was influenced by the type of lactic acid bacteria present 
(Sanni et al., 1999; Bucker et al., 2008). However, as titratable acidity increased, the $\mathrm{pH}$ decreased as a function of fermentation time (Walia et al., 2013).

Apparent viscosity of breadfruit-corn yoghurt was lower than that of commercial milk yoghurt as shown in Fig. 8. Viscosity of food system is usually affected by sugar and other macromolecules through their interaction with the solution or solvent (Zapsalis and Beck, 1985). The level of addition of sugar, corn starch and stabilizers may have influenced the higher viscosity of CMY. Trisnawati et al. (2013) reported the important role played by xanthan gum in the viscosity of soy-corn milk. Walia et al. (2013) stated that yoghurts rheology is described in terms of viscosity, viscosity loss and its recovery, among other considerations. The viscosity loss during storage may be due to microbial and biochemical changes leading to reduction in total solids and sugar. Supavititpatana et al. (2010) reported that the hardness and springiness of corn milk yoghurt and commercial milk yoghurt were reduced with storage time, while the adhesiveness increased, which might be due to degradation of gel structure. Since viscosity is a measure of thickness and thinness of a fluid, such factors leading to gel degradation in yoghurt will invariably reduce the thickness and result to viscosity loss.

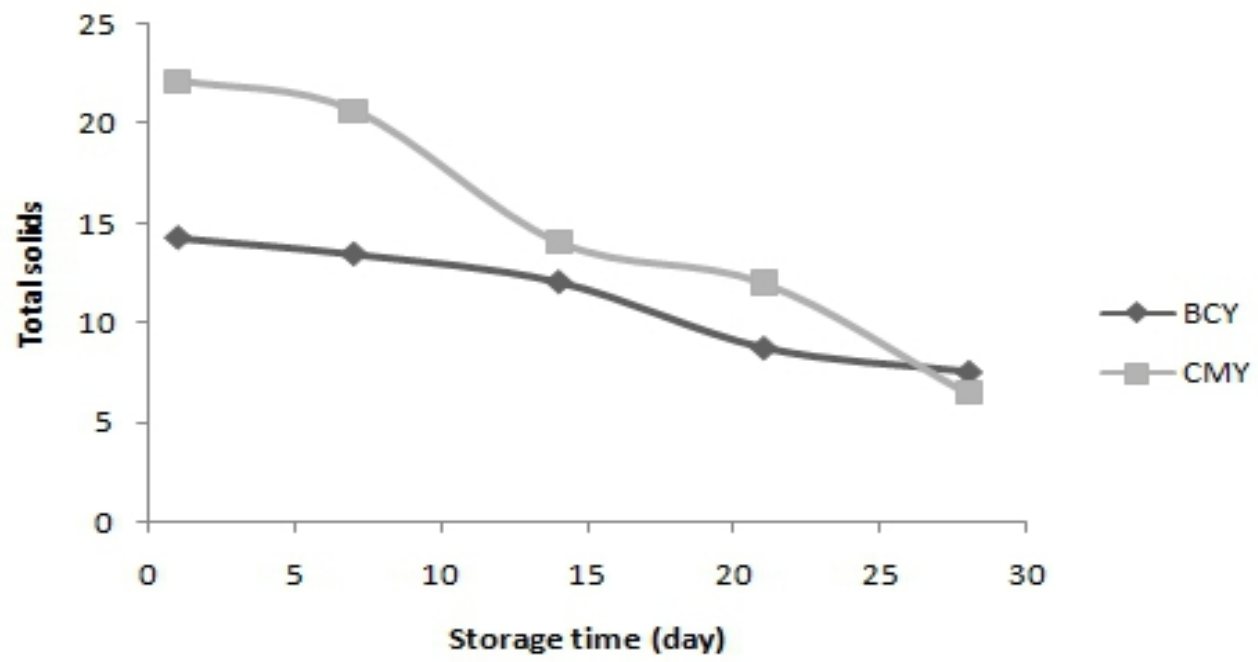

Fig. 5: Changes in total solids of yoghurt samples during storage $\mathrm{BCY}=$ Breadfruit-corn yoghurt, $\mathrm{CMY}=$ Commercial milk yoghurt 


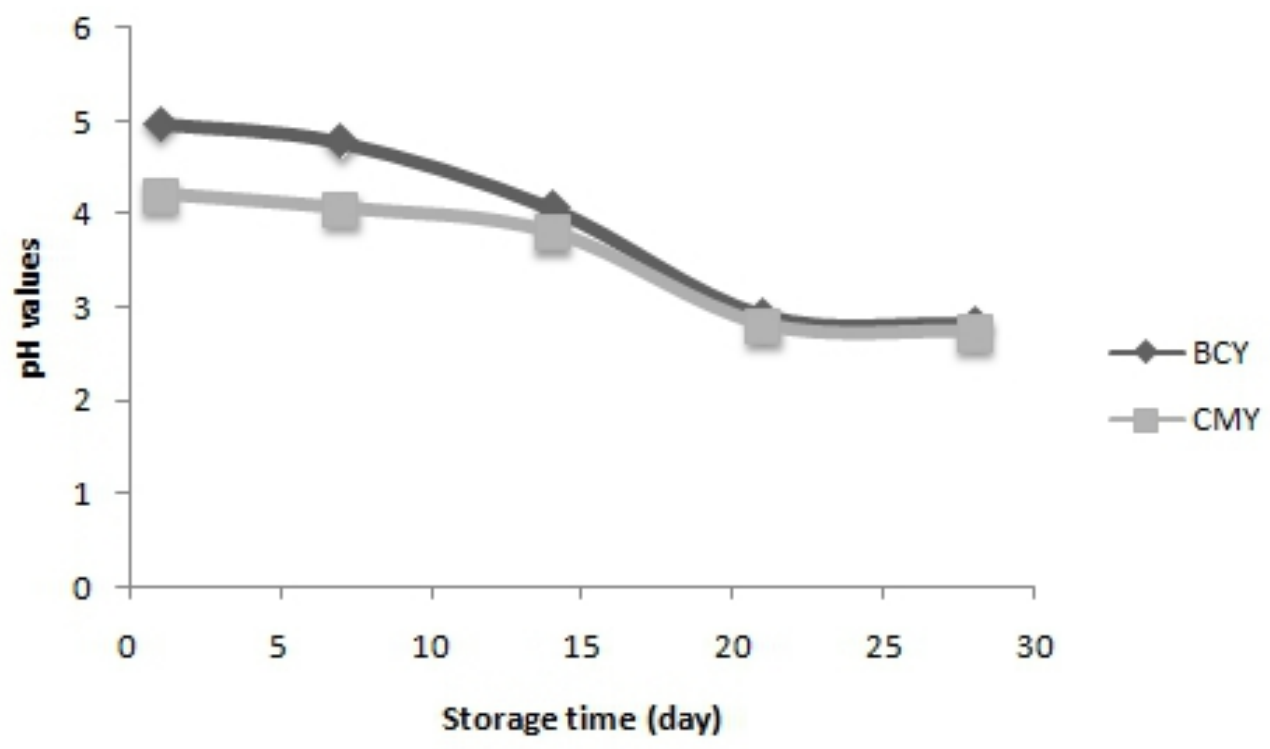

Fig. 6: Changes in $\mathrm{pH}$ of yoghurt samples during storage $\mathrm{BCY}=$ Breadfruit-corn yoghurt, $\mathrm{CMY}=$ Commercial milk yoghurt

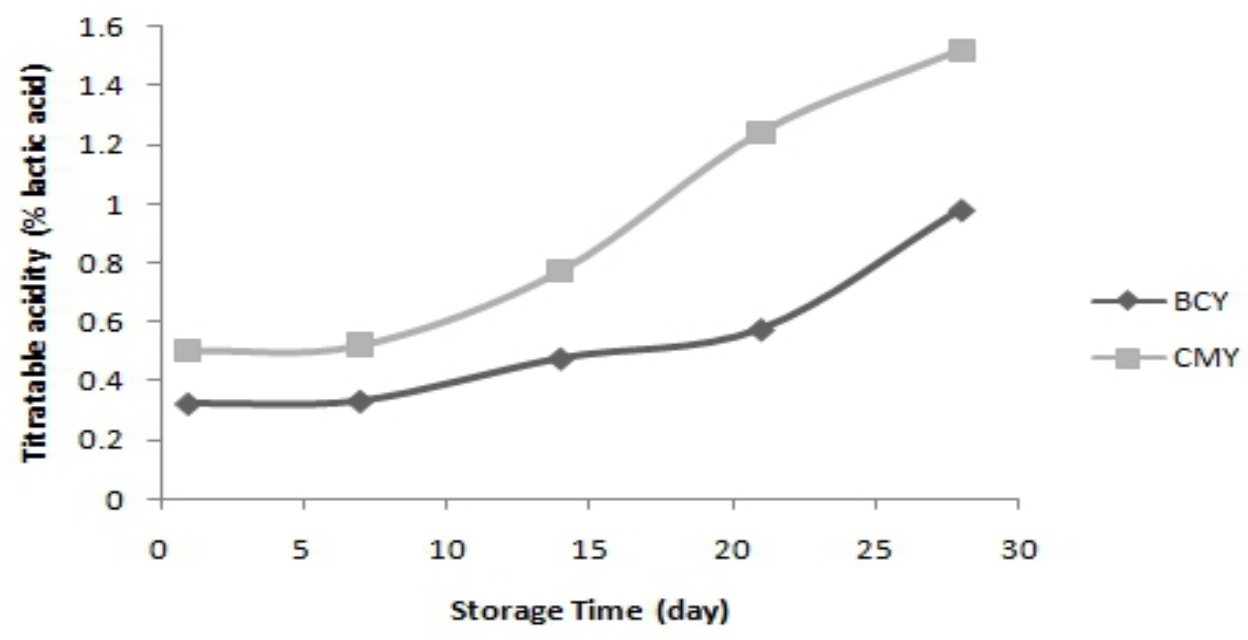

Fig. 7: Changes in titratable acidity of yoghurt samples during storage $\mathrm{BCY}=$ Breadfruit-corn yoghurt, $\mathrm{CMY}=$ Commercial milk yoghurt 


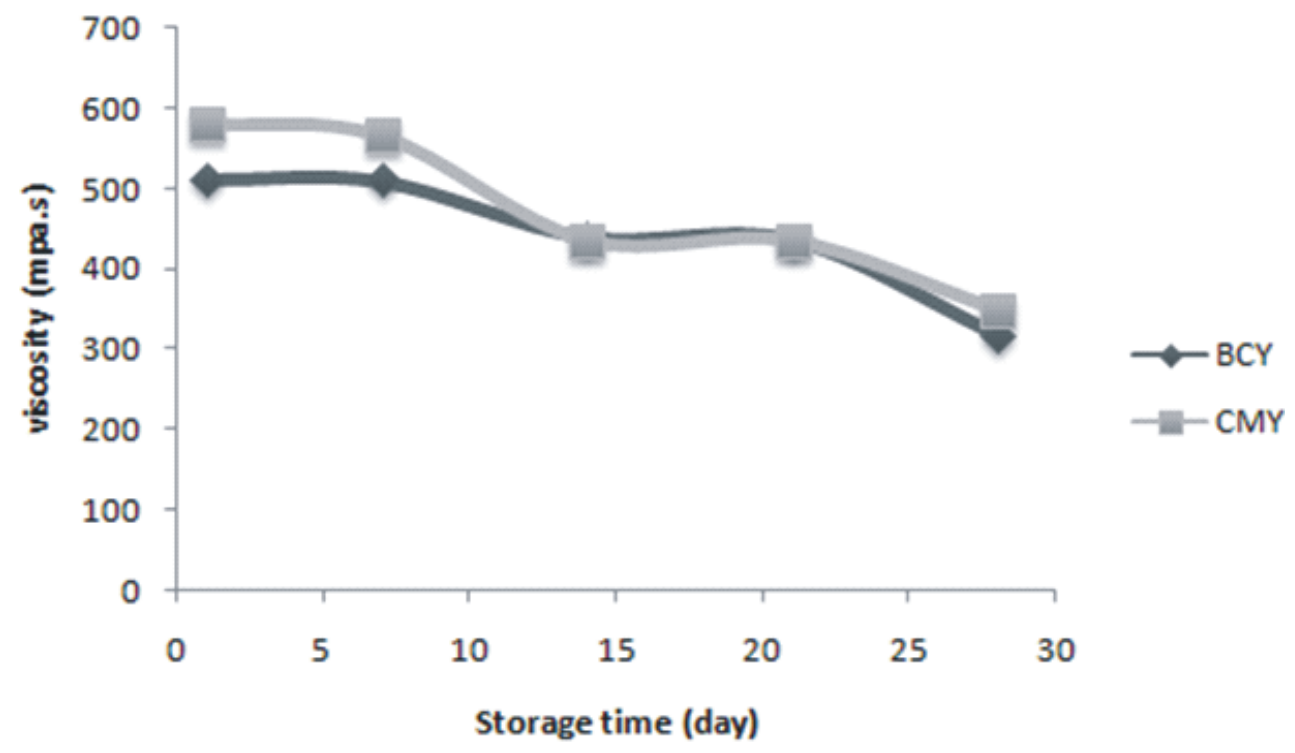

Fig. 8: Changes in apparent viscosity of yoghurt samples during storage $\mathrm{BCY}=$ Breadfruit-corn yoghurt, $\mathrm{CMY}=$ Commercial milk yoghurt

\section{Physical properties}

It can be seen from Table 1 that there was higher syneresis in breadfruit-corn yoghurt than in commercial milk yoghurt. This was similar to the report by Supavititpatana et al. (2010) where corn milk yoghurt exhibited higher syneresis than commercial milk yoghurt. The level of syneresis in the breadfruit-corn yoghurt was higher than the values obtained by Supavatitpatana et al. (2010) for corn milk yoghurt. The lower syneresis of the corn milk yoghurt possibly resulted from the higher gel strength of corn starch and the stabilizers added. The syneresis of CMY was lower than that of the commercial milk yoghurt reported by Supavitipatana et al. (2010). This may possibly be due to addition of corn starch and carboxyl methyl cellulose (CMC) to the commercial yoghurt used in this study, which has the tendency to improve gel strength. Addition of stabilizers such as gelatine or xanthan gum has been reported to have lowered syneressis level in soy yoghurt and soy-corn yoghurt (Estedez et al., 2008; Lestiyani et al., 2014). These findings reflect that stabilizers bind and hold the free water in the system thus impacting the syneresis values. There was increase in syneresis in both yoghurt samples, but there was no significant $(\mathrm{p}>0.05)$ difference in rate of increase during storage. This may be attributed to relative catabolic activities leading to degradation of gel network, which expectedly increased syneresis. Supavititpatana et al. (2010) reported that the gel structure of corn milk yoghurt was harder than that of the cow milk yoghurt, adding that the hardness and springiness of both yoghurts were reduced with storage time, while the 
adhesiveness increased, which could be mainly due to degradation of gel structure.

The whey drainage of the breadfruit-corn yoghurt appeared after 7 days of storage and appreciated over the period of storage. Whey drainage refers to the appearance of whey on the gel structure (Lucey, 2012). The whey drainage is an indication of weakness of the gel network, which reduces the water holding capacity and increases syneresis (Supavititpatana et al., 2010). There was no whey drainage in the commercial milk yoghurt during the 28 days of storage, which agreed with the findings of Supavititpatana et al. (2010) who only recorded whey drainage in corn milk yoghurt compared to the commercial milk yoghurt. There was significant $(\mathrm{p}<0.05)$ difference in rate of changes in whey drainage in both yoghurt samples during the four week storage. The commercial milk yoghurt exhibited higher water holding capacity than the breadfruit-corn yoghurt. Sodini et al. (2004) described the water holding capacity as the method for indirect evaluation of network homogeneity. The higher water holding capacity of the cow milk yoghurt was probably due to better homogenization of milk before fermentation. Homogenization produces small-sized fat globules which absorb more protein on their surface, leading to increased ability to immobilize water (Keogh and O'Kennedy, 1998; Supavititpatana et al., 2010). The finer nature of the cow milk proteins make them more easily absorbed into the small fat globules during homogenization which may have contributed to the higher water holding capacity of the cow milk yoghurt compared to the breadfruit-corn yoghurt. It is possible to improve the water holding capacity of yoghurt depending on ingredients. Fernandez et al. (2006) reported that stabilizers, such as xanthan gum bind the free water, therefore inhibit the water molecules mobility, and form rigid gel structure. Akalin et al. (2012) investigated the effect of sodium calcium caseinate $(\mathrm{NCaCN})$ and whey protein concentrate (WPC) on the water holding capacity of probiotic yoghurt. Addition of whey protein concentrate was reported to have enhanced the water holding capacity of the yoghurt more than the caseinate. Whereas the $\mathrm{NCaCN}$ resulted in a coarse, smooth and more compact protein network, the WPC gave finer and bunched structure in the scanning electron microscopy micrograph. The impact of finer protein structure as reported by these authors ratifies the earlier suggestion that the finer cow milk protein might have contributed to the higher water holding capacity of the commercial milk yoghurt compared to the breadfruit-corn yoghurt. The lower water holding capacity of the breadfruitcorn yoghurt could result in higher syneresis and poor texture of the yoghurt. There was however no significant $(\mathrm{p}<0.05)$ difference in rate of change in water holdind capacity during the storage period. 
Table 1: Some physical properties of yoghurt samples

\begin{tabular}{ccccc}
\hline Yoghurt & $\begin{array}{c}\text { Storage time } \\
\text { (days) }\end{array}$ & Syneresis (\%) & $\begin{array}{c}\text { Whey drainage } \\
(\%)\end{array}$ & $\begin{array}{c}\text { Water holding } \\
\text { capacity }(\%)\end{array}$ \\
\hline & 1 & $37.02^{\mathrm{a}} \pm 0.03$ & $0.00^{\mathrm{a}} \pm 0.00$ & $56.82^{\mathrm{a}} \pm 0.16$ \\
BCY & 7 & $38.04^{\mathrm{a}} \pm 0.06$ & $0.01^{\mathrm{a}} \pm 0.00$ & $57.46^{\mathrm{a}} \pm 0.47$ \\
& 14 & $38.91^{\mathrm{a}} \pm 0.03$ & $0.03^{\mathrm{a}} \pm 0.00$ & $56.05^{\mathrm{a}} \pm 0.07$ \\
& 21 & $40.50^{\mathrm{a}} \pm 0.05$ & $0.08^{\mathrm{a}} \pm 0.01$ & $53.72^{\mathrm{a}} \pm 0.29$ \\
& 28 & $43.06^{\mathrm{a}} \pm 0.06$ & $0.11^{\mathrm{a}} \pm 0.02$ & $48.89^{\mathrm{a}} \pm 0.03$ \\
& 1 & $28.49^{\mathrm{a}} \pm 0.04$ & $0.00^{\mathrm{b}} \pm 0.00$ & $74.01^{\mathrm{a}} \pm 0.03$ \\
CMY & $27.46^{\mathrm{a}} \pm 0.05$ & $0.00^{\mathrm{b}} \pm 0.00$ & $70.23^{\mathrm{a}} \pm 0.02$ \\
& 14 & $27.99^{\mathrm{a}} \pm 0.04$ & $0.00^{\mathrm{b}} \pm 0.00$ & $68.44^{\mathrm{a}} \pm 0.12$ \\
& 21 & $28.02^{\mathrm{a}} \pm 0.01$ & $0.00^{\mathrm{b}} \pm 0.00$ & $65.09^{\mathrm{a}} \pm 0.10$ \\
& 28 & $28.32^{\mathrm{a}} \pm 0.02$ & $0.00^{\mathrm{b}} \pm 0.00$ & $64.87^{\mathrm{a}} \pm 0.04$ \\
\hline
\end{tabular}

Means within a column followed by different superscripts are significantly $(\mathrm{p}<0.05)$ different. BCY=Breadfruit-corn yoghurt, $\mathrm{CMY}=$ Commercial milk yoghurt.

\section{Microbiological qualities \\ Total viable count}

It is seen in Table 2 that the total viable count (TVC) of the breadfruitcorn yoghurt correlated with the value obtained for the commercial milk yoghurt. The high total viable count of the yoghurt samples might be due to the cells of the LAB used in yoghurt fermentation. Lestiyani et al. (2014) reported a total lactic acid bacteria of $6.2 \times 10^{10}$ to $1.46 \times 10^{11} \mathrm{cfu} / \mathrm{ml}$ in soy-corn yoghurt. The total viable count of both yoghurts revealed initial higher growth rate during the first 14 days. Supavititpana et al. (2010) reported increased psychrotrophs count of corn milk yoghurt and cow milk yoghurt during storage but the rate of increase in cow milk yoghurt was lower than that of the corn milk yoghurt. In addition to the starter culture, growth may be attributed to cells of lactic acid bacteria that might have survived processing treatment (Ukwuru and Ogbodo, 2011). The most well known characteristics of lactic acid bacteria related to preservative property are their ability to produce acid which in turn exhibit antimicrobial activity. The slower rate of growth in cow milk may, therefore be partly due to the presence of sorbic acid which was detected as one of the flavor compounds in cow milk yoghurt (Supavititpatana et al., 2010). Sorbic acid and there salts are known to offer antimicrobial activity. Although the addition of potassium sorbate to the breadfruit-corn yoghurt might have conferred some preservative effect, but the natural occurrence of sorbic acid in the cow milk yoghurt and further introduction of the salt might have increased efficacy. The organic acids and the bacteriocines produced by the lactic acid bacteria are great potentials to be used in food preservation which are considered as safe natural preservatives. However, Affonso and Maria (1999) reported the occurrence of after acidification and proteolysis during yoghurt storage which occurred because of the enzymatic 
activity of lactic acid bacteria, which although reduced at refrigeration temperature, was not completely stopped. This corroborated previous report by Brough et al. (1993) that different degrees of coagulation occurred in different milk products with no chemical preservation. More investigation is required to determine chemical preservatives that complement acidification in order to extend the shelf stability of yoghurts giving the incessant power outage that affect efficient cold preservation in developing countries. However, such preservatives must not exceed the permissible level by the regulatory agencies.

\section{Mould count}

There was mould growth in both samples of yoghurt on day 1 as shown in Table 2. Mould growth was more rapid in the breadfruit-corn yoghurt apparently due to higher acidity and total solid of the commercial milk yoghurt. The higher moisture content of the breadfruit-corn yoghurt may also have contributed to the more rapid growth. Supavititpatana et al. (2010) reported changes in the yeast and mould counts of cow milk yoghurt and corn milk yoghurt which was similar to that of psychrotrophs. The higher rate of changes in this study may be attributed to temperature fluctuations due to unsteady power supply during the storage.Direct use of anti-fungal strains as protective cultures present important application value to the food industry (Li et al., 2013). In a yoghurt preservation period experiment and mould proof accelerated testing at $4^{\circ} \mathrm{C}$, addition of $2 \%(\mathrm{v} / \mathrm{v})$ Lactobacillus casei AST18 in yoghurt completely inhibited the growth of Penicillum sp, which was used as indicator fungi (Widyastuti et al., 2014). Supavitipatana et al. (2010) reported that the shelf life of corn milk and cow milk at $5^{0} \mathrm{C}$ was 14 days. The mould count of $1.0 \times 10^{4} \mathrm{cfu} / \mathrm{ml}$ of breadfruit-corn yoghurt and $4.5 \times 10^{3} \mathrm{cfu} / \mathrm{ml}$ of commercial milk yoghurt on day 14 of storage were within the limit of acceptance $\left(2.0 \times 10^{5} \mathrm{cfu} / \mathrm{ml}\right)$ for dairy products by Codex Alimentarius Commission (FAO/WHO, $2002 \mathrm{a}, \mathrm{b}$ ).

Table 2: Microbiological quality of yoghurt samples during 28 days storage

Storage period (days)

Microbial Count (cfu/ml)

\begin{tabular}{|c|c|c|c|c|c|c|c|c|c|c|}
\hline \multirow{3}{*}{ Sample } & \multicolumn{10}{|c|}{$x^{2}$} \\
\hline & \multicolumn{2}{|c|}{1} & \multicolumn{2}{|c|}{7} & \multicolumn{2}{|c|}{14} & \multicolumn{2}{|c|}{21} & \multicolumn{2}{|c|}{28} \\
\hline & TVC & Mould & TVC & Mould & TVC & Mould & TCV & Mould & TVC & Mould \\
\hline $\mathrm{BCY}$ & $1.75 \times 10^{5}$ & $5 \times 10^{2}$ & $2.8 \times 10^{5}$ & $1.5 \times 10^{3}$ & $6.5 \times 10^{6}$ & $1.0 \times 10^{4}$ & $1.9 \times 10^{7}$ & $4.0 \times 10^{5}$ & $4.9 \times 10^{7}$ & $3.0 \times 10^{5}$ \\
\hline CMY & $1.8 \times 10^{5}$ & $1.5 \times 10^{3}$ & $1.8 \times 10^{5}$ & $7.0 \times 10^{3}$ & $2.7 \times 10^{6}$ & $4.5 \times 10^{3}$ & $1.35 \times 10^{7}$ & $3.0 \times 10^{5}$ & $1.04 \times 10^{8}$ & $1.0 \times 10^{5}$ \\
\hline
\end{tabular}

$\mathrm{BCY}=$ Breadfruit-corn yoghurt; $\mathrm{CMY}=$ Commercial milk yoghurt 


\section{Conclusion}

This research has shown that non-dairy yoghurt derived from blend of African breadfruit milk and corn milk possessed relevant characteristics similar to dairy yoghurt. The effects of storage on the physicochemical properties and microbiological qualities of the yoghurt so obtained correlated with that of cow milk yoghurt. Perhaps more research on appropriate starter cultures and fermentation procedure for dairy free yoghurts might lead to products of common gel structure and physical characteristics with the cow milk yoghurt.

\section{References:}

1. Adeiye, O.A., Gbadamosi, S.O. and Taiwo, A.K. (2013). Effects of some processing factors on the characteristics of stored groundnut milk extract. African Journal of Food Science, 7(6): 134 - 142.

2. Afonso, I.M, and Maria, J.M. (1999).Rheological monitoring of structure evolution and development in stirred yoghurt. Journal of Food Engineering, 42:183-190.

3. Akalin, A.S, Unal, G., Dinkci ,N. and Hayaloglu, A.A. (2012). Microstructural, textural and sensory characteristics of probiotic yoghurts fortified with sodium calcium caseinate or whey protein concentrate. Journal of Dairy Science, 95(7): 3617-3628.

4. American Public Health Association APHA (1995). 3112B, Cold Vapour Atomic Absorption Spectrometric Method, Standard Methods for Examination of Water and Wastewater, 20 ${ }^{\text {th }}$ Edition, APHA, AWWA, WEF.

5. AOAC (1990). Association of Analytical Chemistry. Methods for Proximate Analysis. 2217 - 2280.

6. Belewu, M.A., Belewu, K.Y. and Bamidele, R.A. (2010). Cypercoconut yoghurt preparation, compositional and organoleptic qualilities. African Journal of Food Science and Technology, 1 (1) : $010-012$.

7. Birollo, G.A., Reinheinmer, J.A. and Vinderola, C.G. (2000). Viability of lactic acid microflora in different types of yoghurt. Food Research International, 33: 799-805.

8. Brough, S.H., Azam-Ali, S.N. and Taylor, A.J. (1993). The potential of bambara groundmut in vegetable milk production and basic protein functionality systems. Food Chemistry, 47(3): 277-283.

9. Bucker, J.R., Mitchell, J.H. and Johnson, M.G. (2008). Lactic acid fermentation of peanut milk. Journal of food Science, 44(5) : 1534 1538 .

10. Buono, M., Larry, E., Fung, D. and Jeon, I.J. (1990). Carbohydrate utilization and growth kinetics in the production of yoghurt from 
soymilk part 1: experimental methods. Journal of Food Processing and Preservation, 13: 135-153.

11. Chien, J.T. and Synder, H.E. (1983). Detection and control of soymilk astringency. Journal of Food Science, 48: 438-440.

12. Delavenne, E., Mounier, J., Deniel, F., Barbier, G. and Le Blay, G. (2012). Biodiversity of antifungal lactic acid bacteria isolated from raw milk samples from cow, ewe and goat over one-year period. International Journal of Food Microbiology, 155(3): 185-190.

13. DeVos, W..M (1996). Metabolic Engineering of Sugar Catabolism in lactic acid bacteria. Antonio van Leuwenhoek, 70: 223-24

14. Elsamani, M.O., Isam, A. and Ahmed, M. (2014). Physichochemical characteristics and organolepitic properties of peanuts milk-based yoghurt fortified with skimmed milk powder. Journal of Research in Applied Sciences, 4: 78:82.

15. Estedez, A.M., Majia, J., Figuerola, F. and Escobar, B. (2008). Effect of solid content and sugar combination on the quality of soymilk yoghurt, Journal of Food Processing and Preservation, 34: 87-97.

16. FAO/WHO (2002a). Milk and milk products. Joint FAO/WHO Food Standards Programme. Codex Alimentarius Commission. 42pages.

17. FAO/WHO (2002b). Joint FAO/WHO expert report diet, nutrition and the prevention of chronic diseases. In: Food and Nutrition Bulletin, 24: 255-256.

18. Fernadez, P.P., Martino, M.N., Zaritzky, N.E., Guignon, B. and Sanz, P.D. (2006). Effects of locust bean, xanthan and guar gums on the ice crystals of a sucrose solution frozen at high pressure. Food Hydroidloid, 21(4): 507-515.

19. Granata, L.A. and Morr, C.V. (1996). Improved acid, flavour and volatile compound production in a high protein and fibre soymilk yoghurt-like product. Journal of Food Science, 61(2): 331-336.

20. Isanga, J. and Zhang, G. (2009).Production and evaluation of some physicochemical parameters of peanut milk yoghurt. Food Science and Technology, 42(6): 1132 - 1138.

21. Jimoh, K.O. and Kolapo, A.I. (2007).Effect of different stabilizers on acceptability of soy yoghurt. African Journal of Biotechnology, 6(8): 1000-1003.

22. Keogh, M.K and O'kennedy, B.T. (1998).Rheology of stirred yoghurt as affected by added milk fat, protein and hydrocolloids. Journal of Food Science, 63(1): 108 - 112.

23. Kongo, J.M. (2013). Lactic acid bacteria as starter cultures for cheese processing: past, present and future developments. 15pages.

24. Kpodo, F.M.K., Afoakwa, E.O, Amoa, B.B., Busdu, A.S. and Saalia, F.K. (2014a).Nutritional and sensory characterization of full fat and 
partially defatted peanut soymilk yoghurt. International Journal of Nutrition and Food Science, 3(3): 187 - 193.

25. Kpodo, F.M.K., Afoakwa, E.O., Amoa, B.B., Busdu, A.S. and Saalia, F.K. (2014b).Effect of ingredient variation on microbial acidification, susceptibility to syneresis, water holding capacity and viscosity of soypeanut-cow milk yoghurt. Journal of Nutritional Health and Food Engineering, 1(2): 1-6.

26. Kumar, P. and Mishra, H.H. (2004). Mango soy fortified set yoghurt: effect of stabilizer addition on physicochemical, sensory and textural properties. Food Chemistry, 87: 501-507.

27. Lal, S.N.D., O'Connor, C.J. and Eyres, L. (2006). Application of emulsifiers/stabilizers in dairy products of high rheology. Advances in Colloid and Interface Science, 123: 433-437.

28. Lee, S.Y., Morr, C.V. and Seo, A. (1990). Comparison of milk based and soymilk based yoghurt. Journal of Food Science, 55(2): 532 - 536.

29. Lestiyani, A.D., Susano, T.I. and Srianta, I. (2014). Characteristics of soy-corn yoghurt. Journal of Food and Nutritional Disorders, 3(2): 1 -3 .

30. Li. H., Liu, L., Zhang, S., Uluko, H., Ciu, W. and Liv, J. (2013). Potential use of Lactobacillus casei AST18 as a bioprotective culture in yoghurt. Food Control,34(2): 675-680.

31. Lucey, J.A. (2002). Foundation Scholar award formation and physical properties of milk protein gels. Journal of Dairy Science 85: 281 294.

32. Mayra-Makmen, A. and Bigret, M. (2004).Industrial use and production of lactic acid bacteria. Marcel Dekker, Inc. New York. 198pages.

33. Mennane, Z., Khedid, K., Zinedine, A., Lazouli, M., Ouhssiane, M. and Elychioni,M. (2007). Microbial characteristics of Klila and Iben traditional Moroccan cheese from raw cow's milk. World Journal of Dairy and Food Sciences, 2(1): 23 -27.

34. Miral, B. and Steinkraius, R.H.K. (1999).Fermentation of soymilk by lactic acid bacteria. Revised Journal of Food Science, 41: 895-899.

35. Moon, S.K., Wee, Y.J. and Choi, G.W. (2012). A novel lactic acid bacterium for the production of high purity lactic acid. Journal of Bioscience and Bioengineering, 114(2): 155-159.

36. Ogbulie. J.N, Uwaezuoke, J.C. and Ogiehor, S.I. (1998). Introductory Microbiology Practical. Sprufield Publishers, Owerri. pp. 60-62.

37. Olakunle, M.M. (2012).Production and quality evaluation of soy-corn yoghurt. Advanced Journal of Food Science and Technology, 4(3): 130-134. 
38. Onweluzo, L.J.C. and Nwakalor ,C. (2009). Development and evaluation of vegetable milk from Treculia africana (Decne) seeds. Pakistan Journal of Nutrition, 8: 233-238.

39. Panesar, P.S. (2011). Fermented dairy products: starter cultures and potential nutritional benefits. Food and Nutrition Sciences, 2(1): 4751.

40. Park, D.J., Oh, S., Ku, K.H., Mok, C., Kim, S.H. and Imm, J.Y. (2005).Characteristics of yoghurt-like products prepared from the combination of skim milk and soymilk containing Saccharified-rice solution. International Journal of Food Science and Nutrition, 56(1): 23-34.

41. Parnell-Clunies, E.M., Kakuda, Y., Mullen, K.., Armon, D.R. and deMan, J.M. (1986). Physical properties of yoghurt: a comparison of vat versus continuous heating systems of milk. Journal of Dairy Science, 69: 2593-2603.

42. Rao, R.D., Pulusani, R.S, and Chawan, B.B.C. (1988). Technical note: preparation of yoghurt-like product from cowpeas and mung beans. International Journal of Food Science and Technology, 28:195.

43. Rehman, S.,Hussain, H.,Nawaz, H.,Ahmad, M.M.,Huma,N. and Virk, W.A. (2007). Preparation and quality evaluation of Lathyrus sativus Lbovine milk blend. Pakistan Journal of Nutrition, 6: 134-137.

44. .Routrary, W. and Mishra, H.H. (2011). Scientific and technical aspects of yoghurt aroma and taste: review. Comprehensive Reviews in Food Science and Food Safety, 10(4): 208 - 220.

45. Sanni, A.I., Onilude, A.A., Adeleke, E.O. (1999). Preparation and characteristics of lactic acid fermented cowpea milk. Lebensm Unters Forsch, A 208:225-229.

46. Sexena,S. and Singh, G. (1997).Suitability of new soybean cultivar in the production of soymilk. Journal of Food Science and Technology, 34:150-152.

47. Sharma, R., Sanodiya, B.S., Bagrodia, D., Pandey, M., Sharma, A. and Bisen, P.S. (2012). Efficacy and potential of lactic acid bacteria modulating human health. International Journal of Pharmacy and Bio Science, 3(4): 935-938.

48. Sodini, F., Remeuf, F., Haddad, S. and Corrieu, G. (2004). The relative effect of milk base, starter and process on yoghurt texture: a review. Critical reviews in food science and Nutrition, 44: $113-137$.

49. Supavititpatana, P., Wirjantoro, T. and Raviyam, P. (2010).Characteristics and shelf-life of corn milk yoghurt. $C M U$ Journal of Natural Science, 9(1): 133-147. 
50. Trisnawati, C.Y., Srianra, I. and Marsono, Y. (2013). Effect of varieties on the characteristic of soy-corn milk. International Food Research Journal, 20(3): 1187 - 1190.

51. Udeozor, L.O. (2012). Tiger nut-soy milk drink: Preparation, proximate composition and sensory qualities. International Journal of Food and Nutrition Science, 1(4): 18-26.

52. Ukwuru, M.U., Omachona, L.J. and Onoka, N. (2008).Production and quality assessment of Tiger nut (Cyperus esculentus) imitation milk during storage. Journal of Food Science and Technology, 45:180-188.

53. Ukwuru, M.U. and Ogbodo, A.C. (2011). Effect of processing treatment on the quality of tiger nut milk. Pakistan Journal of Nutrition, 10(1): 95-100.

54. Vasiljevic, T. and Jelen, P. (2002). Lactose hydrolysis in milk as affected by neutralizers used for the propagation of crude Bgalactosidose extracts from Lactobacillus bulgaricus 11842 . Innovative Food Science and Engineering Technology, 3: 175 - 184.

55. Walia, A., Mishra, H.N. and Kumar, P. (2013).Effect of fermentation on physicochemical, textural properties and yoghurt bacteria in mango soy fortified yoghurt. African Journal of Food Science, 7(6): 120-127.

56. Wang, V.C., Yu, R.C and Chou, C.C. (2002). Growth and Survival of Bifidobacteria and lactic acid bacteria during the fermentation and storage of cultured soymilk drinks. Food microbiology, 19: 501 - 508.

57. Wheeler, J.R. and Gulufes, J.A. (1973), Banana milk fruit food, Australian Journal of Dairy Technology. 28(3): 96-99.

58. Widyastuti, V., Rohmatus, S. and Febrisintosa, A. (2014). The role of lactic acid bacteria in milk fermentation. Food and Nutrition Sciences, 5: 435-442.

59. Wouters, J.T.M. , Ayad, E.H.E., Hugenholtz, J. and Smit, G. (2002). Microbes from raw milk for fermented dairy products. International Dairy Journal, 12(2-3) : 91-109.

60. Zanhi, N.K. and Jideani, I.A. (2012). Physicochemical and sensory qualities of soy and milk solids fortified low fat yoghurt. African Journal of Agricultural Research, 7(38): 5336-5343.

61. Zapsalis, C. and Beck, R.A (1985). Food Chemistry and nutritional biochemistry Willey, New York. 